\title{
The Impediments and Best Practice use of Derivatives in Zimbabwe, Botswana and South Africa
}

Wilbert Kudakwashe Chidaushe*

CME Group Foundation (USA), Botho University, Botswana

\begin{abstract}
The research investigates into the impediments and the best practice use of derivatives in Zimbabwe, Botswana and South Africa. The research has been based on a mixed method research approach. The significance of the study has been to identify the gaps in the use of derivatives and the factors that have given rise to the gaps. It has been revealed that Banks in Zimbabwe only use the simple forward agreements derivative to hedge risk. In Botswana only simple forward agreements, foreign currency exchange swaps, credit default swaps and currency options are commonly used by international banks as hedging instruments. In South Africa a broad range of simple and complicated derivatives are fairly used, such as financial futures and options, as well as derivatives in commodities.
\end{abstract}

Keywords: Derivatives; Impediments; Best practice use

\section{Background to the Problem}

\section{Background to the study}

In accordance to Greenberger, the early derivative market products were used in the year 1865 in the USA in Chicago by farmers to protect against price risk in corn, wheat, other grains and by then all derivatives were referred to as futures contract [1].

Hull [2] defined a derivative as a financial instrument with a value that is derived from the price of other basic underlying variables or traded assets. Hull reiterated that derivatives can be reliant on almost any variable for instance from the prices of hogs and to the amount of snow falling at a specific place of resort [2].

There are four common types of derivatives that exist in the world such as:

- Forward Contracts-Hull regarded a forward contract as a simple derivative involving an agreement between counterparties to buy or sell an asset at a specified future date for a certain price agreed in advance. The forward contracts are not exchange traded [2].

- Futures Contracts-Hull defined a futures contract as agreement between two parties to buy or sell an asset at a certain time in the future at a certain price. Futures contracts are traded on regulated exchanges and have standardized features [2].

- Swaps Contract-the International Swaps Derivatives Association (ISDA) in 2010 defines a "swap" as a derivative where two counterparties exchange streams of cash flows with each other. These streams of cash flows were known as "legs" of the swap and are calculated with reference to the notional amount.

- Options Contract-Hull considered an option as giving the holder the right to buy (call option) or sell (put option) an underlying asset by a certain date for a certain price. The two basic types of options are Put and Call options. A call option is the right and not an obligation to buy an underlying asset and a put option is the right and not an obligation to sell an underlying asset. The put and call options are sometimes regarded as "plain vanilla" or standard derivatives [2].

The derivatives can also be categorized into exchange traded derivatives and OTC (over the counter derivatives). Hull regarded Over the Counter derivatives (OTC) as those derivative products that are non-standardized and vice versa [2].

Global derivatives markets: The global derivative markets comprise of the Chicago Mercantile Exchange group (CME), the Chicago Board of Trade (CBT), New York Mercantile Exchange (NYME), Philadelphia Stock Exchange, Commodity Exchange (COMEX), London International Financial Futures and Options Exchange (LIFFE), National Stock Exchange of India (NSEI), Intercontinental Exchange, Moscow Exchange, Eurex Exchange, Shaghayi Futures Exchange, Nasdaq etc. (Table 1).

\begin{tabular}{|c|c|c|c|c|}
\hline & Dec 2013 & Dec 2014 & Dec 2015 & Dec 2016 \\
\hline Futures & 12.13 & 12.14 & 14.48 & 15.89 \\
\hline Options & 9.42 & 9.69 & 10.30 & 9.33 \\
\hline Total & 21.55 & 21.83 & 24.78 & 25.22 \\
\hline
\end{tabular}

Source: 2016 FIA Annual Volume Survey: Global Futures and Options Volume.

Table 1: The world volumes of trading of futures and options (in billions of contracts).

The above table depicts the volume of derivatives that were traded all over the world from 2013 to 2016 on international exchanges. The number of futures and options derivatives that were exchanged on international derivatives exchanges increased from approximately 21.55 billion contracts in 2013 to 25.22 billion of contracts in 2016 .

Regional derivatives markets: The regional derivatives markets include the Johannesburg Stock exchange (JSE) in South Africa and deals with a variety of derivative products on energy, metals, commodities and currency derivatives including futures, options and swaps. Another regional derivatives exchange is the Zambia Commodity Exchange (ZAMACE) and in 2016 the JSE exchange signed a partnership agreement with ZAMACE exchange to boost

*Corresponding author: Wilbert Kudakwashe Chidaushe, CME Group Foundation (USA), Botho University, Botswana, Tel: 026773114289; E-mail: Wilbert.chidaushe@bothouniversity.ac.bw

Received March 20, 2018; Accepted April 17, 2018; Published April 27, 2018

Citation: Chidaushe WK (2018) The Impediments and Best Practice use of Derivatives in Zimbabwe, Botswana and South Africa. J Bus Fin Aff 7: 333. doi: 10.4172/2167-0234.1000333

Copyright: $\odot 2018$ Chidaushe WK. This is an open-access article distributed under the terms of the Creative Commons Attribution License, which permits unrestricted use, distribution, and reproduction in any medium, provided the original author and source are credited. 
liquidity in the commodity and financial markets of Zambia. The Zambia commodity exchange deals in white maize, wheat and soya futures and options contracts.

Characteristics of derivatives markets: The main characteristics of derivatives are;

- Derivatives are products whose value is derived from the value of the underlying assets.

- Derivatives are highly leveraged or geared, that is with a small initial outlay can enable one to deal in larger volumes of trade.

- Pricing and trading of derivatives is complex as there is a need to understand the price behaviour and structure of the underlying prior to trading in derivatives.

Uses of derivative markets: Derivatives are used by hedgers, arbitrageurs and speculators as explain below:

- Hedging is a mechanism through which the investor uses derivatives to protect his assets from the risk of erosion of value due to adverse movements of the prices in the markets.

- Speculators' uses derivatives to make profits by anticipating the general movements of the prices in the market.

- Arbitrageurs make riskless profit by exploiting price differentials in the markets through the use of derivatives.

- Derivatives are used for price discovery.

- Derivatives are used to develop the cash market.

- Derivatives are used to develop capital markets

- Derivatives are used for risk transfer

- Provide business opportunities to domestic financial firms.

The necessary conditions for the development of derivatives markets: The development of derivative markets will only be successful if the conditions necessary for successful business are present. The task force for the International Organization for Securities Commission (IOSCO) [3] regarded the following factors as encouraging the successful development of derivatives.

\section{i) Economic conditions}

Most countries with a successful futures and options derivative exchanges have relatively stable economies (low or moderate inflation) and relatively high GDP. Derivatives are not suitable for products whose price is controlled by the government. Although low inflation is clearly desirable for a futures or options exchange it is not a necessary condition for the successful development of the derivative market. For example, Brazil with a high rate of inflation, it has a very successful futures exchange.

\section{ii) Financial infrastructure}

A country with a well-developed financial infrastructure will be in a better position to develop derivative markets than that without. The following are regarded as important elements of the financial infrastructure.

\section{a) Clearing and settlement system}

The clearing house should ensure the clearance of both sides of the transaction. In-order for the clearing and settlement system to exit and be able to fulfil its obligations several conditions must be met including, the existence of margining requirements and a system for timeous payment to members of the clearing system and this require effective coordination with the banking sector.

\section{b) Personnel}

There must be qualified personnel, in addition to those who take orders and execute orders, to perform back office tasks that include compliance, product development and clearing and settlement. Therefore, formal training programs are needed.

\section{c) International participation}

A plan to develop a derivative market should consider the extent it will be part of or affected by the international financial system. Integration should be evaluated from two perspectives the degree of participation by international traders and the degree of participation of domestic users in other foreign markets.

\section{d) Financial integrity}

Financial integrity is a clear characteristic of a successful derivative exchange and there are two aspects of financial integrity that firms must be strong enough to warranty customer business and the clearinghouse system must be strong enough to protect the strong members from the weak ones.

\section{iii) Legal and regulatory framework}

One necessary condition for the development of a successful derivative exchange is that the activity must be permitted by law and derivatives contracts must be legally enforceable. For Futures trading government regulations should be imposed and the generally accepted regulations on them should include financial integrity, market integrity and customer integrity. Some of rules should govern exchange trading, clearing and settlement, exchange membership and the activities of financial intermediaries. Other rules should be imposed by the government regulators and whilst others must be imposed by selfregulatory organizations.

\section{iv) Market structure}

A derivative exchange must be able to survive in the environment it will be operating. This environment includes the extent of development of the underlying cash market, the linkages of the derivative market with cash market, the type of competition to be faced by the derivative exchange, the type of market participation anticipated, the availability of risk capital, the strength of the financial infrastructure and the nature of the potential market makers.

Most successful derivatives are separate entities and are membership organizations as they are owned and managed by their members.

\section{v) Knowledge of derivatives}

The investors or customers should be aware of the benefits that accrue as a result of using derivatives in the markets. Those responsible for legal and regulatory oversight should be convinced of the benefits of the derivatives to the society in order to impose the necessary and appropriate regulations for derivatives on the market.

\section{vi) Timing of market development}

There is no prescription for the timing of market development as markets can grow according to a government plan or by themselves. However, it has been observed that cash markets precede derivatives and that derivative markets help in the development of the cash market. 
The necessary regulatory frameworks for derivatives: The necessary regulations for derivatives comprise the Dodd-Frank wall street reform Act of the USA, the USA Commodities Futures Trading Commission (CFTC) regulations, European Market Infrastructure of the EU and regulations by the International Organization for Securities Commission (IOSCO) are the first and foremost substantial laws that regulate the OTC derivatives markets.

Dodd frank wall street reform and consumer protection act: The Dodd Frank Wall Street Reform and Consumer Protection Act, was promulgated in July 2010 by the US government.

The following are the main prescribed obligation to be complied with by G20 member countries in dealing with OTC derivatives regulations under title VII, of the Wall Street Transparency and Accountability Act of the Dodd Frank Act of July 2010;

i) Mandatory contract clearing with a Derivatives Clearing Organization (DCO) of certain swaps or security-based swaps.

ii) Reporting to a trade repository the details of all swaps, within 15 minutes for mandatory clearable swaps and between 1 to 2 hours for non-mandatory cleared swaps.

iii) Margin rules for non-cleared swaps, these include requirements for both initial and variation margin, as well as rules on segregation.

iv) Mandatory exchange trading for all mandatory cleared swaps on a Designated Contract Market (DCM) or Swap Execution Facility (SEF) when those swaps have been made available to trade by SEF and DCM.

v) Provisions to include speculative position limits in certain commodities derivatives market for spot and non-spot months.

vi) The details of end user and inter-affiliate exemptions from the scope of the rules.

\section{Statement of the problem}

Since the financial crisis of 2008 Zimbabwe and Botswana have not set up a derivative exchange to address risk in the markets and the study is concerned primarily on exploring the factors that are inhibiting Zimbabwe and Botswana from using derivatives in their markets.

Therefore, the statement of the problem is on what are the impediments to the development of commodities and currency derivative markets in Zimbabwe and Botswana?

\section{Research questions}

Main Research question

1. What are the impediments to the development of commodities and currency derivative markets in Zimbabwe and Botswana?

Sub-research questions

2. What is the best practice use of derivative in Zimbabwe, Botswana and South Africa?

3. What is the impact on payoff that result from the use of derivatives in Zimbabwe, Botswana and South Africa?

\section{Purpose of the study}

The purpose of the study is to examine into the factors that hinder the development of derivative markets and to recommend practical regulatory frameworks for the implementation of derivative markets in Zimbabwe and Botswana.

\section{Objectives of the study}

The objective of the study is to explore the factors that affect the establishment of derivative markets and to examine the appropriate regulatory framework for the development of derivative markets in Zimbabwe and Botswana.

\section{Significance of the study}

The significance of the study to Zimbabwe, Botswana and South Africa investors: The significance of the study is for capacity building of institutional investors concerning the regulatory frameworks and necessary conditions for the development of derivative markets in Zimbabwe and Botswana.

The significance of the study to Zimbabwe and Botswana is to inform investors in these countries of the benefits of using derivatives in protecting their wealth from erosion caused by price volatility.

The significance of the study is to inform policy makers of the importance of developing derivative markets in Zimbabwe and Botswana.

\section{Review of Related Literature}

This section contains the conceptual and theoretical framework for the study and including the literature review. The review of literature has been categorized into the conditions necessary for the development of derivatives, the impediments of using derivatives and the impact of using derivatives.

\section{Conceptual framework}

In accordance to Huberman and Robson conceptual framework has been regarded as the system of assumptions, concepts, beliefs, expectations and theories that informs and support the research and is the key component of the research design [4].

Jabareen [5] defined conceptual framework as a plane of interlinked concepts that support the understanding of a phenomenon and that establish a framework specific philosophy. Further Jabareen asserted that conceptual frameworks have epistemological, ontological and methodological assumptions and each concept within a conceptual framework plays an epistemological or ontological role [5].

Guba and Lincoln related ontological assumptions to the knowledge of the way things are or the nature of reality, whilst epistemological assumptions relate to how things really are and how things really work in an assumed reality [6].

The conceptual framework for the study is therefore based on grounded theory. According to Glaser and Strauss defined grounded theory as a research method that is applied to discover theory from data obtained systematically [7]. Therefore, the study aims to discover theory through the identification of gaps and the impediments to the development of derivative markets by obtaining data systematically, through conducting primary data research in the financial markets of Zimbabwe and Botswana, In addition the study shall examine the global regulatory framework for the establishment of derivative markets.

\section{Theoretical framework}

Liehr and Smith [8] defined theoretical framework as a structure of concepts which exists in the literature and as a ready-made map 
for the study. The theoretical framework for the study shall be based on derivative laws and regulations and on derivatives best practices theories including, international derivatives market reforms, international standards for derivatives, international regulatory framework for derivatives and models for the effective self-regulation of derivative markets.

The theoretical framework of the study is based on derivatives, derivatives laws and regulations based on the USA Dodd Frank Act and the regulations of the Commodity Futures Trading Commission (CFTC), including the International market reforms for OTC derivatives that were pledged by the G-20 leaders through the International Organization for Securities Commission (IOSCO), Basel Committee for Banking Supervision (BCBS), Committee for Payment and Settlement Systems (CPSS) and Bank for International Settlements (BIS).

\section{Review of literature}

Several researchers have explored into the factors that affect and facilitate the development of derivative markets.

The conditions necessary for the development of derivative markets: Gibson [9] mentioned the following factors as important for the successful implementation of a derivative market, volatility of prices, size of the market, standardization and some market liberalization as the key parameters of setting up a derivative market.

Tsetsekos and Varangis [10] unveiled that emerging markets require non-competing derivative markets with enforceable contracts, efficient cash markets, with many traders and speculators, legal structures that include property rights, the support of government and policy makers and sufficient financial resources.

Bodie et al. [11] on an investigation on derivative market development in different countries with a focus on Chilean derivative market recommended that institutional and legal factors should be flexible to facilitate the development of the derivative market. The findings from the same study revealed that impediments to the establishment of derivatives in Chilean markets were mostly legal constraints on the institutional investors.

According to Adelegan and Banks, derivatives markets are selfregulatory in relation to their activities, the activities of their members and their clients but however for the establishment of a successful derivative exchange a sound regulatory environment is vital $[12,13]$.

Bekale [14] in their study institutionalization of derivatives trading and growth-evidence from South Africa, stated that the establishment of a vibrant, well supervised and well-regulated derivative markets is crucial to avoid the risks of derivative aggravated disasters occurring and hence the need to anticipate the infrastructural requirements of these markets. This is supported by Pickel that adequate infrastructure need to be put in place to support the evolution of innovative derivatives products [15].

Hawkesby [16] further explained that arbitrage opportunities, ability to leverage transactions, liquidity, transparency and low transaction costs as the major factors that attract financial institutions to the use of different derivative products. Further Baluch and Ariff mentioned that the most critical factor driving the successful operation of any derivative market is the liquidity in the underlying markets [17].

Alberta market solutions [18], Pickel [15], Tsetsekos and Varangis [10] agreed that derivative innovations should be supported by evolving up to date regulations of the market at all times.

The impediments to the development of derivative markets: Hawkesky [16] affirmed that shortages of cash resources (liquidity) as a critical impediment to the establishment of financial instruments as investors would not be able to buy or sell their holdings at a reasonable volume.

Standley [19] stated that an efficient derivative market would not be achieved in the short-term but derivative trading should follow on the exchanges for equities and bonds that provide in turn the need for derivative trading.

Haiss and Sammer [20] postulated that derivatives have the power to destabilize the markets and have an ability to increase systemic risk causing trouble in the financial systems.

Impact of using derivatives to investors and their portfolios: Hamilton [21] proposed that developing countries can use derivatives to fight against the volatility of commodity prices as forward prices are less volatile than spot prices. The Deustche Bundesbank report confirmed that a derivative exchange provides transparent information to the underlying cash market and thereby playing an important role in price discovery in the underlying market [22].

Chilsholm [23] postulated that derivative markets enable global capital markets integration by enhancing the global allocation of savings and thereby promoting greater investment levels.

According to Chagwiza [24] in the study "liquidity derivatives as a solution to Zimbabwean economic liquidity problems", stated that introducing a derivative to the Zimbabwean market as crucial to the country's economic and liquidity growth as countries in the region such as South Africa, Nigeria and Kenya have proved the necessity and importance of the derivative market for economic development.

Dodd and Tian reaffirmed that the derivatives are a requirement to strengthen the financial markets $[25,26]$. Bessis [27] stated that the purpose of derivatives is to serve as insurance against unwarranted price movements and hence reduce the variability of company cash flows resulting in reliable cash flow forecasting, lower capital requirements and greater capital productivity.

Baluch and Ariff and Sendeniz-Yüncü et al. agreed that higher economic growth are experienced in countries that have established derivative markets than those without $[17,28]$.

In addition, Kumari and Ngugi et al. stressed that derivatives can lead to both capital market development and towards financial markets completeness $[29,30]$.

Rodrigues et al. [31] confirmed that derivative markets makes firms' risk management cheaper, reduces the costs of running the business and free capital that can be invested in high growth projects leading to increased economic growth. According to Rodrigues firms that use derivatives have an access to more growth opportunities. Kirkpatrick affirmed that derivatives can promote competition in the markets and the development of sophisticated business environments [32].

Argument, research gap to be filled by the current study and justification of the research: In Botswana the Non-Banking Financial Regulatory Authority (NBFIRA) published the revised 2017 version of the fund investment rules (PFR2) with regard to pension prudential rules in terms of section 4 (d) of the NBFIRA Act of 2016 which is read with section 52 of the Retirement Funds act of 2014, with regard to the use of pension funds, it was provided that, a fund shall not use derivatives 
other than for the purpose of efficient portfolio management and for the purpose of reducing investment risk, upon obtaining approval in writing from an actuary. Derivatives are regarded to be at the infancy stages of development at the Botswana Stock Exchange (BSE).

Nhavira [33] revealed that the financial crisis of 2008 left investors in Zimbabwe vulnerable to systemic risk build ups and this was contributed in part by OTC derivatives and partly by an inappropriate regulatory and supervisory frameworks that was in place at the Reserve Bank of Zimbabwe.

Considering the foregoing it is undoubtedly clear that there are no relevant regulatory frameworks in Zimbabwe and Botswana that provide for derivative trading and as a result there is a need to reform the regulatory frameworks for Zimbabwe and Botswana to incorporate the evolution of OTC derivatives, in-order to appropriately address systemic risk.

In addition the current literature [22-31], mostly focuses on the impact of using derivatives and does not recommend specific regulatory frameworks or models that should be implemented for the effective conduct and supervision of the derivatives markets of Zimbabwe and Botswana and hence as a result this study aims to fill this gap.

\section{Research Methodology and Design/Methods}

\section{Introduction}

The following section looks at the research methodology, research paradigm and the research design of the study. The section also focuses on data collection, data presentation, data analysis and interpretation procedures and ends with consideration of the ethical issues relating to the study.

\section{Research methodology and paradigm}

Methodology: Crotty [34] defines methodology as the strategy or plan of action which lies behind the choice and use of particular methods. Methodology is concerned with why, what, from where, when and how data is collected and analyzed. Guba and Lincoln [6] explain that methodology asks the question: how can the inquirer go about finding out whatever they believe can be known?

Qualitative research methodology was prevalently used and combined with quantitative research in the study and was integrated with the case study strategy which fit well with the qualitative approach at verifying and scrutinizing the impediments to the initiation of derivatives exchanges and the best use of derivative products in Zimbabwe, Botswana and South Africa.

Chilisa and Preece [35] described qualitative research as concerning about people' experiences, in their natural settings and employs a variety of approaches including observations and interviews and that the report findings are mostly descriptive and not in statistics. Lincoln and Guba [36] further confirmed qualitative research as a study where humans are the essential instruments as the studies are set in their natural settings. McMillan [37] described qualitative research as a study where the meaning and understanding rely on observations and narratives instead of numbers.

The qualitative research methodology is justifiable for this research as a rich in-depth detail was possible to obtain from the participants on the impediments to the development of derivative markets and the participants can elaborate their responses through use of open ended questionnaires and focus group interviews and thus participants' perceptions can be considered.
The major draw backs of qualitative research technique is that it is subjective and often because of small sample sizes the results cannot be generalized. The results of a qualitative research can be accused of being unreliable at times as different results can be obtained on a different day with different people being interviewed and finally the conclusions based on qualitative research would need to be substantiated.

Research paradigm: According to Scotland a paradigm consists of the following components: ontology, epistemology, methodology, and, methods [38]. Kuhn regarded research paradigm as a set of common agreements and beliefs shared about how problems should be addressed and understood [39]. Guba and Lincoln described research paradigms as characterized through their ontology (what is reality?), epistemology (How do you know something?) and methodology (How do you go about finding it out?) [6].

Crotty [34] regarded Ontology as the study of being and that ontological assumptions focuses on what constitute reality. Cohen et al. [40] claimed that epistemology is concerned with the nature and forms of knowledge and the epistemology assumptions are concerned with how knowledge can be created, acquired and communicated and what it means to know. Further Guba and Lincoln [6] insisted that epistemology is associated with the question, what is the nature of the relationship between would be knower and what can be known?

The research used interpretivists research paradigm perspective as primary data collected through Interpretivism studies is associated with a high level of validity as the data in such studies tends to be honest and trustworthy.

The interpretivist research philosophy is appropriate to the study as the researcher's interest was integrated into the study through the active participation by the researcher in the collection and interpretation of the data obtained on the impediments and best practice development of derivative markets in Zimbabwe and Botswana.

The interpretive perspective was relevant to this study as it is based on the naturalistic approaches of data collection such as through interviews and observations. In addition, secondary data research is also common with the philosophy of interpretivism and the meanings usually emerge at the end of the research process.

The main drawbacks of the interpretivist philosophy are that it is subjective in nature, the researcher might be biased, and the data collected through interpretive studies cannot be generalized since the data is greatly impacted by personal values and viewpoint. Hence the representativeness and the reliability of the data obtained through an interpretive approach is undermined to a certain extent.

Research design or methods: Crotty [34] defined methods as the specific procedures and techniques that are used to collect and analyse data.

Bloomberg and Volpe, Rowley and Yin regarded a research design as the logic that links the research questions and purpose to the processes for empirical data collection, analysis, in order to arrive at the conclusions drawn from the data [41-43]. Creswell affirmed that the research design implies or relies on the chosen research paradigm [44].

The research design used in the study was the case study approach. Jurs describes a case study as the examination of a situation, single group, individual or site in detail. Stake regarded a case study as a study of a 'particular' [45]. Adelman described a case study as a study of an instance in action [46].

Merrian alluded that the purpose of such case studies is to provide 
an intensive, holistic description and analysis of a single, bounded unit situated in a specific context to provide insight into real-life situations [47].

According to Kaplan, Parke, Orlikowski and Baroudi proclaimed that a case study strategy can be used when the organizational settings are socially intricate [48-50].

Other researchers also indicated the following situations as appropriate for using the case study strategy:

i) When there are particular events that are focused on a situation or context that have specificity $[51,52]$;

ii) When a researcher is looking for contextual meaning within a system that is bounded [53-55]; and

iii) When the research enterprise is inductive theory building $[52,56,57]$.

Population: The units from which the sampling framework was drawn comprised of the institutions in the money and capital market of Harare in Zimbabwe, Gaborone in Botswana and Johannesburg in South Africa.

Sample: One hundred (100) interview administered questionnaires with open ended questions were issued to respondents in each of the financial markets of Zimbabwe, Botswana and South Africa.

Ten (10) one on one in depth interviews with financial experts in each country's commercial banking sector and capital markets were conducted.

Two (two) focus group interviews or seminars with financial experts, one from the central bank of each country and the other with experts from the financial sector of each country were conducted.

Two (2) in depth interviews with leading academics at the institutes of higher learning in each country were carried out.

Sampling procedure: The research employed purposive random sampling and convenient sampling of individuals holding executive or managerial positions at financial institutions in Zimbabwe, Botswana and South Africa.

Accordance to Bernard [58] purposive random sampling is regarded as non-random sampling technique where the researcher decides what needs to be known and find out people who can and are willing to provide the information by virtue of their knowledge and experience. The researcher purposively selects the participants that are perceived to have something to offer in relation to the investigation. Purposeful sampling relies on selecting data elements that have the potential to give the greatest insight into the research questions. In the intended study, purposive sampling technique was best for qualitative research studies as it selected respondents who served the intended purpose of the research study.

Instruments: The study used;

i) One on one in-depth interviews.

ii) Semi-structured interview administered questionnaires with closed and open ended questions.

iii) Focus group interviews.

\section{Data presentation, analysis and interpretation procedures}

Creswell [44] proposed that when analyzing data, the qualitative researcher should attempt to make sense and interpret the phenomena in terms of the meaning the participants place on them. Shaw proclaimed that a variety of qualitative data analysis methods such as, content analysis, constant comparison and pattern matching can be used, and that whichever approach is chosen qualitative researchers should make the process involved in their collection and analysis of data as explicit as possible [59]. Shaw insisted that researchers employing qualitative methods that fail to do so "do little to encourage theory development or to progress current knowledge and understanding" [59].

The study used predominantly pattern matching to analyze the data. The information gathered was put in categories and a template analysis followed the outline of the project proposal. A template is proposed to be a list of categories that represent the themes revealed by the data that has been collected. Saunders et al. key themes and patterns were identified during one on one interviews and from focus group interviews were matched with themes that emerged from the questionnaires [60]. Challenges and impacts and best practices were developed and tested based on the themes and patterns that were identified from the interviews and questionnaires.

The research findings were analyzed using Microsoft Excel as well as SPSS software in drawing the conclusions (Table 2).

\begin{tabular}{|c|c|c|c|}
\hline Sources & Size of Sample & No. of Responses & Response Rate (\%) \\
\hline South Africa & 100 & 72 & 72 \\
\hline Botswana & 100 & 100 & 100 \\
\hline Zimbabwe & 100 & 96 & 96 \\
\hline
\end{tabular}

Table 2: Study response rate.

\section{Data Presentation, Analysis, Discussion and Interpretation}

\section{Summary of the effectiveness of derivatives in addressing risk in the foreign currency markets of South Africa}

South Africa: In South Africa the study showed that currency futures (75\%), currency quanto futures (59\%), forward contracts $(59 \%)$, currency options (58\%), maxi currency futures (50\%), bond futures (50\%), bond index futures (50\%) and forex swaps (50\%) are effective instruments in addressing exposures in the financial markets in South Africa. The results of the study confirmed Dodd (2004) and Tian (2005)'s findings that the derivatives are a requirement to strengthen the financial markets (Table 3).

\section{Summary of the effectiveness of derivatives in addressing risk in the foreign currency markets of Botswana}

Botswana: In Botswana, of the few respondents that were using derivatives, the study revealed that forex swaps (29\%), forward contracts (25\%), long term interest rate futures (13\%), interest rate caps $(12 \%)$, interest rate floors (12\%), currency futures (12\%), short-term interest rate futures (8\%) and long term interest futures (8\%) are effective at addressing risks in the financial markets (Table 4). The results of the findings confirm Bessis's findings that the purpose of derivatives is to serve as insurance against unwarranted price movements and hence reduce the variability of company cash flows resulting in reliable cash flow forecasting, lower capital requirements and greater capital productivity [27].

Zimbabwe: In Zimbabwe few participants use forward contract hedge, $13 \%$ of the sample studied confirmed that simple forward contracts are effective in addressing exposures in the financial markets. The results of the findings confirm Chagwiza's findings in the study "liquidity derivatives as a solution to Zimbabwean economic liquidity 
Citation: Chidaushe WK (2018) The Impediments and Best Practice use of Derivatives in Zimbabwe, Botswana and South Africa. J Bus Fin Aff 7: 333. doi: $10.4172 / 2167-0234.1000333$

Page 7 of 12

\begin{tabular}{|c|c|c|c|c|c|}
\hline & Very effective & Fairly effective & Not very effective & Not effective at all & Do not know \\
\hline \multicolumn{6}{|l|}{ Derivative Instrument: } \\
\hline Currency futures & $67 \%$ & $8 \%$ & $0 \%$ & $0 \%$ & $25 \%$ \\
\hline Currency quanto futures & $17 \%$ & $42 \%$ & $0 \%$ & $16 \%$ & $25 \%$ \\
\hline Maxi currency futures & $25 \%$ & $25 \%$ & $8 \%$ & $8 \%$ & $33 \%$ \\
\hline African currency futures & $8 \%$ & $17 \%$ & $17 \%$ & $16 \%$ & $42 \%$ \\
\hline Currency options & $50 \%$ & $8 \%$ & $8 \%$ & $0 \%$ & $34 \%$ \\
\hline Short-term interest rate futures & $25 \%$ & $8 \%$ & $8 \%$ & $17 \%$ & $42 \%$ \\
\hline Long-term interest rate futures & $33 \%$ & $8 \%$ & $8 \%$ & $8 \%$ & $43 \%$ \\
\hline Bond futures & $33 \%$ & $17 \%$ & $0 \%$ & $8 \%$ & $42 \%$ \\
\hline Bond index futures & $33 \%$ & $17 \%$ & $0 \%$ & $8 \%$ & $42 \%$ \\
\hline Interest rate caps & $8 \%$ & $25 \%$ & $0 \%$ & $8 \%$ & $59 \%$ \\
\hline Interest rate floor & 0 & $25 \%$ & $0 \%$ & $8 \%$ & $67 \%$ \\
\hline Interest rate collar & $8 \%$ & $25 \%$ & $0 \%$ & $8 \%$ & $59 \%$ \\
\hline Forward contract hedge & $42 \%$ & $17 \%$ & $0 \%$ & $8 \%$ & $33 \%$ \\
\hline Forex swaps & $50 \%$ & $0 \%$ & $8 \%$ & $8 \%$ & $34 \%$ \\
\hline Money market hedge & $8 \%$ & $33 \%$ & $0 \%$ & $8 \%$ & $51 \%$ \\
\hline
\end{tabular}

Table 3: The effectiveness of derivatives in addressing risk in the foreign currency markets of South Africa.

\begin{tabular}{|c|c|c|c|c|c|}
\hline & Very effective & Fairly effective & Not very effective & Not effective at all & Do not know \\
\hline \multicolumn{6}{|l|}{ Derivative Instrument: } \\
\hline Currency futures & $0 \%$ & $0 \%$ & $0 \%$ & $0 \%$ & $100 \%$ \\
\hline Currency quanto futures & $0 \%$ & $0 \%$ & $0 \%$ & $0 \%$ & $100 \%$ \\
\hline Maxi currency futures & $0 \%$ & $0 \%$ & $0 \%$ & $0 \%$ & $100 \%$ \\
\hline African currency futures & $0 \%$ & $0 \%$ & $0 \%$ & $0 \%$ & $100 \%$ \\
\hline Currency options & $4 \%$ & $8 \%$ & $0 \%$ & $0 \%$ & $88 \%$ \\
\hline Short-term interest rate futures & $4 \%$ & $4 \%$ & $0 \%$ & $0 \%$ & $92 \%$ \\
\hline Long-term interest rate futures & $0 \%$ & $13 \%$ & $0 \%$ & $0 \%$ & $87 \%$ \\
\hline Bond futures & $0 \%$ & $0 \%$ & $0 \%$ & $0 \%$ & $100 \%$ \\
\hline Bond index futures & $0 \%$ & $0 \%$ & $0 \%$ & $0 \%$ & $100 \%$ \\
\hline Interest rate caps & $4 \%$ & $8 \%$ & $0 \%$ & $0 \%$ & $88 \%$ \\
\hline Interest rate floor & $4 \%$ & $8 \%$ & $0 \%$ & $0 \%$ & $88 \%$ \\
\hline Interest rate collar & $0 \%$ & $8 \%$ & $0 \%$ & $0 \%$ & $92 \%$ \\
\hline Forward contract hedge & $8 \%$ & $17 \%$ & $0 \%$ & $0 \%$ & $75 \%$ \\
\hline Forex swaps & $8 \%$ & $21 \%$ & $0 \%$ & $0 \%$ & $71 \%$ \\
\hline Money market hedge & $0 \%$ & $13 \%$ & $0 \%$ & $0 \%$ & $88 \%$ \\
\hline
\end{tabular}

Table 4: Effectiveness of derivatives in addressing risk in the foreign currency markets of Botswana.

problems" [24], stated that introducing a derivative to the Zimbabwean market as crucial to the country's economic and liquidity growth as countries in the region such as South Africa, Nigeria and Kenya have proved the necessity and importance of the derivative market for economic development.

\section{Summary of the effectiveness of derivatives in addressing risk in the commodities markets of South Africa}

South Africa: In South Africa the respondents revealed that options (92\%), futures (91\%), grain futures and options (92\%), soy complex futures and options (67\%), corn futures and options (67\%), gold futures and options (58\%), copper futures and options (50\%), silver futures and options (50\%), crude oil futures and options (50\%), beef futures (41\%), diesel hedge futures and options (33\%) and hard red winter wheat futures and options (25\%) are effective at addressing risk in the commodities markets (Table 5). The results of the study confirms the findings by Hamilton that developing countries can use derivatives to fight against the volatility of commodity prices as forward prices are less volatile than spot prices [21].

Botswana: In Botswana the respondents revealed that commodity derivatives are not in use at all in addressing risks in the markets.
Zimbabwe: In Zimbabwe the market participants revealed that they were not using commodity derivatives at the time the survey was conducted.

\section{Summary of the results of the impediments of using derivatives in South Africa}

South Africa: In South Africa the responses revealed that factors such, economic conditions (67\%), political and bad governance (67\%), shortage of skilled staff (50\%), legal and contractual factors $(50 \%)$, technological factors (34\%) are challenges hindering the use derivatives in South Africa. The results of the study confirm Bekale findings in their study institutionalization of derivatives trading and growth-evidence from South Africa, stated that the establishment of a vibrant, well supervised and well-regulated derivative markets is crucial to avoid the risks of derivative aggravated disasters occurring and hence the need to anticipate the infrastructural requirements of these markets (Table 6) [14].

Summary of the results of the impediments of using derivatives in Botswana

Botswana: In Botswana the enquiry showed that, legal and contractual factors (34\%), shortage of skilled staff (34\%), technological 
Citation: Chidaushe WK (2018) The Impediments and Best Practice use of Derivatives in Zimbabwe, Botswana and South Africa. J Bus Fin Aff 7: 333. doi: $10.4172 / 2167-0234.1000333$

Page 8 of 12

\begin{tabular}{|c|c|c|c|c|c|}
\hline & Very effective & Fairly effective & Not very effective & Not effective at all & Do not know \\
\hline \multicolumn{6}{|l|}{ Derivative Instrument: } \\
\hline Options & $75 \%$ & $17 \%$ & $0 \%$ & $0 \%$ & $8 \%$ \\
\hline Futures & $83 \%$ & $8 \%$ & $0 \%$ & $0 \%$ & $9 \%$ \\
\hline Grain futures \& options & $67 \%$ & $25 \%$ & $0 \%$ & $0 \%$ & $8 \%$ \\
\hline Soy complex futures and options (CBOT) & $50 \%$ & $17 \%$ & $17 \%$ & $0 \%$ & $16 \%$ \\
\hline Soft red wheat futures \& futures (CBOT) & $25 \%$ & $17 \%$ & $33 \%$ & $0 \%$ & $25 \%$ \\
\hline Hard red winter wheat & $17 \%$ & $8 \%$ & $42 \%$ & $0 \%$ & $33 \%$ \\
\hline Corn futures \& options & $42 \%$ & $25 \%$ & $17 \%$ & $0 \%$ & $16 \%$ \\
\hline Gold futures \& options & $33 \%$ & $25 \%$ & $25 \%$ & $0 \%$ & $17 \%$ \\
\hline Copper futures \& options & $17 \%$ & $33 \%$ & $33 \%$ & $0 \%$ & $17 \%$ \\
\hline Silver futures \& options & $25 \%$ & $25 \%$ & $25 \%$ & $8 \%$ & $17 \%$ \\
\hline Crude oil futures \& options & $25 \%$ & $25 \%$ & $25 \%$ & $8 \%$ & $17 \%$ \\
\hline Diesel hedge futures \& options & $25 \%$ & $8 \%$ & $25 \%$ & $17 \%$ & $25 \%$ \\
\hline Weather & $33 \%$ & $0 \%$ & $8 \%$ & $17 \%$ & $42 \%$ \\
\hline Real estate & $0 \%$ & $17 \%$ & $8 \%$ & $17 \%$ & $58 \%$ \\
\hline Diamond futures & $8 \%$ & $0 \%$ & $0 \%$ & $17 \%$ & $75 \%$ \\
\hline Beef futures & $8 \%$ & $33 \%$ & $17 \%$ & $8 \%$ & $34 \%$ \\
\hline
\end{tabular}

Table 5: Effectiveness of derivatives in addressing risk in the commodities markets of South Africa.

\begin{tabular}{|c|c|c|c|c|c|}
\hline & A very big challenge & $\begin{array}{l}\text { A fairly big } \\
\text { challenge }\end{array}$ & $\begin{array}{l}\text { Not a very big } \\
\text { challenge }\end{array}$ & $\begin{array}{c}\text { Not a challenge } \\
\text { at all }\end{array}$ & Do not know \\
\hline \multicolumn{6}{|l|}{ Factor } \\
\hline Political \& bad governance & $50 \%$ & $17 \%$ & $8 \%$ & $0 \%$ & $25 \%$ \\
\hline Obsolete it systems and models & $17 \%$ & $17 \%$ & $16 \%$ & $25 \%$ & $25 \%$ \\
\hline Economic conditions & $42 \%$ & $25 \%$ & $0 \%$ & $8 \%$ & $25 \%$ \\
\hline Shortage of skilled staff & $17 \%$ & $33 \%$ & $25 \%$ & $0 \%$ & $25 \%$ \\
\hline Legal and other contractual & $33 \%$ & $17 \%$ & $17 \%$ & $8 \%$ & $25 \%$ \\
\hline Cultural & $8 \%$ & $8 \%$ & $25 \%$ & $25 \%$ & $25 \%$ \\
\hline Religious beliefs & $0 \%$ & $0 \%$ & $17 \%$ & $50 \%$ & $33 \%$ \\
\hline Environmental factors & $8 \%$ & $17 \%$ & $33 \%$ & $17 \%$ & $25 \%$ \\
\hline Beef futures & $8 \%$ & $33 \%$ & $17 \%$ & $8 \%$ & $34 \%$ \\
\hline
\end{tabular}

Table 6: Results of the impediments of using derivatives in South Africa.

\begin{tabular}{|c|c|c|c|c|c|}
\hline & A very big challenge & $\begin{array}{l}\text { A fairly big } \\
\text { challenge }\end{array}$ & $\begin{array}{l}\text { Not a very big } \\
\text { challenge }\end{array}$ & $\begin{array}{c}\text { Not a challenge } \\
\text { at all }\end{array}$ & Do not know \\
\hline \multicolumn{6}{|l|}{ Factor } \\
\hline Political \& bad governance & $0 \%$ & $4 \%$ & $17 \%$ & $54 \%$ & $25 \%$ \\
\hline Obsolete it systems and models & $0 \%$ & $25 \%$ & $25 \%$ & $17 \%$ & $33 \%$ \\
\hline Economic conditions & $4 \%$ & $13 \%$ & $38 \%$ & $17 \%$ & $29 \%$ \\
\hline Shortage of skilled staff & $13 \%$ & $21 \%$ & $29 \%$ & $13 \%$ & $25 \%$ \\
\hline Legal and other contractual & $13 \%$ & $21 \%$ & $25 \%$ & $17 \%$ & $25 \%$ \\
\hline Cultural & $0 \%$ & $21 \%$ & $21 \%$ & $25 \%$ & $33 \%$ \\
\hline Religious beliefs & $0 \%$ & $4 \%$ & $13 \%$ & $46 \%$ & $38 \%$ \\
\hline Environmental factors & $8 \%$ & $0 \%$ & $4 \%$ & $50 \%$ & $38 \%$ \\
\hline Beef futures & $8 \%$ & $33 \%$ & $17 \%$ & $8 \%$ & $34 \%$ \\
\hline
\end{tabular}

Table 7: Results of the impediments of using derivatives in Botswana.

issues (25\%), economic conditions (17\%) political and bad governance (4\%), are relatively not a challenge and encumbrance to the implementation of derivatives in Botswana. In the absence of obstacles to establishment of derivative market in Botswana then implementation of derivative market would require the support of the government and policy makers. Tsetskos and Varangis unveiled that emerging markets require non competing derivative markets with enforceable contracts, efficient cash markets, with many traders and speculators, legal structures that include property rights, the support of government and policy makers and sufficient financial resources (Table 7) [10].

Summary of the results of the impediments of using derivatives in Zimbabwe

Zimbabwe: In Zimbabwe the study uncovered that economic conditions (94\%), legal and contractual factors $(72 \%)$, political and bad governance (72\%), technological issues (56\%), shortages of skilled staff (38\%), environmental issues $(56 \%)$ are the factors that are challenges and inhibitive in using derivatives in the country. The findings confirm Bodie et al. findings on an investigation on derivative market development in different countries with a focus on Chilean derivative market that institutional and legal factors should be flexible to facilitate the development of the derivative market (Table 8) [11].

\section{Summary of the best practice use of using derivatives in the foreign currency markets of South Africa}

South Africa: In South Africa the respondents unanimously agreed that futures with margin payments calls (100\%), use of clearing house and settlement system (100\%), use of futures contracts with limit order 
Citation: Chidaushe WK (2018) The Impediments and Best Practice use of Derivatives in Zimbabwe, Botswana and South Africa. J Bus Fin Aff 7: 333. doi: $10.4172 / 2167-0234.1000333$

Page 9 of 12

(100\%) and futures contract with stop limit order (100\%) are the best practice techniques of hedging risks in the markets. In addition, the respondents strongly agreed on marking to market of future contracts (91\%), minimum government intervention in the operations of the exchange (92\%) and the integration of options and futures markets with global markets $(75 \%)$, as best practice requirements of using derivatives to hedge exposures. The results of the findings confirm Adelegan, Banks's findings that derivatives markets are self- regulatory in relation to their activities, the activities of their members and their clients but however for the establishment of a successful derivative exchange a sound regulatory environment is vital (Table 9) $[12,13]$.

\section{Summary of the best practice use of using derivatives in the} foreign currency markets of Botswana

Botswana: In Botswana of the few participants that use derivatives the study revealed that minimum government intervention (21\%), use of a forward contract involving a bank (21\%), use of clearing house and settlement system (21\%), using swap arrangement including a bank (12\%) and use of options contract linked to global markets (4\%) are the best practice use of derivatives in the financial markets. The results confirm Chilsholm's findings that derivative markets enable global capital markets integration by enhancing the global allocation of savings and thereby promoting greater investment levels (Table 10) [23].

\section{Summary of the best practice use of using derivatives in the foreign currency markets of Zimbabwe}

Zimbabwe: In Zimbabwe, a few participants using the simple forward contracts agreed that minimum government intervention (56\%) and use of forward contracts involving a bank (12\%) are the best practice in the use of derivatives in the market. This result of the study confirms Gibson's findings that the following factors are important for the successful implementation of a derivative market, volatility of prices, size of the market, standardization and some market liberalization as the key parameters of setting up a derivative market (Table 11) [9].

\section{Summary of the impact on payoff of derivatives in addressing risk in the foreign currency markets of South Africa}

South Africa: Use of options (75\%), Futures (75\%) and Grain futures and options (67\%) have a huge impact on pay off in addressing risk in the foreign currency markets of South Africa as revealed by the outcome of the respondents. However, Corn futures and options (50\%) and crude oil futures and options (50\%) have also a huge impact on pay offs but at a lesser extent. The results confirm Hawkesby's findings that arbitrage opportunities, ability to leverage transactions, liquidity, transparency and low transaction costs as the major factors that attract financial institutions to the use of different derivative products (Table 12) $[16]$.

\section{Key Findings}

The key findings in the countries studied were; Futures, options and swaps are effective at addressing risk in the financial and commodity markets of South Africa.

Economic conditions, political and bad governance, shortages of skilled staff, legal and contractual factors and technological factors are barriers to the effective use of derivatives in Zimbabwe and Botswana.

The best practice of using derivatives includes applying futures with margin payments calls, the use of clearing house and use of futures with limit and stop order. Marking to market of futures contracts, minimum government intervention in operation of the exchange and the integration of local derivative markets with global derivative markets.

\begin{tabular}{|c|c|c|c|c|c|}
\hline & $\begin{array}{l}\text { A very big } \\
\text { challenge }\end{array}$ & $\begin{array}{l}\text { A fairly big } \\
\text { challenge }\end{array}$ & $\begin{array}{l}\text { Not a very big } \\
\text { challenge }\end{array}$ & $\begin{array}{c}\text { Not a challenge } \\
\text { at all }\end{array}$ & Do not know \\
\hline \multicolumn{6}{|l|}{ Factor } \\
\hline Political \& bad governance & $44 \%$ & $18 \%$ & $25 \%$ & $13 \%$ & $0 \%$ \\
\hline Obsolete it systems and models & $25 \%$ & $31 \%$ & $38 \%$ & $6 \%$ & $0 \%$ \\
\hline Economic conditions & $63 \%$ & $31 \%$ & $6 \%$ & $0 \%$ & $0 \%$ \\
\hline Shortage of skilled staff & $19 \%$ & $19 \%$ & $19 \%$ & $43 \%$ & $0 \%$ \\
\hline Legal and other contractual & $19 \%$ & $63 \%$ & $13 \%$ & $5 \%$ & $0 \%$ \\
\hline Cultural & $13 \%$ & $19 \%$ & $31 \%$ & $31 \%$ & $6 \%$ \\
\hline Religious beliefs & $6 \%$ & $6 \%$ & $19 \%$ & $56 \%$ & $13 \%$ \\
\hline Environmental factors & $25 \%$ & $31 \%$ & $13 \%$ & $31 \%$ & $0 \%$ \\
\hline
\end{tabular}

Table 8: Results of the impediments of using derivatives in Zimbabwe.

\begin{tabular}{|c|c|c|c|c|c|}
\hline & $\begin{array}{l}\text { Strongly } \\
\text { agree }\end{array}$ & $\begin{array}{l}\text { Tend to } \\
\text { agree }\end{array}$ & $\begin{array}{c}\text { Neither agree nor } \\
\text { disagree }\end{array}$ & $\begin{array}{l}\text { Tend to } \\
\text { disagree }\end{array}$ & $\begin{array}{l}\text { Strongly } \\
\text { disagree }\end{array}$ \\
\hline \multicolumn{6}{|l|}{ Best practice use } \\
\hline Marking to market the futures & $83 \%$ & $8 \%$ & $9 \%$ & & \\
\hline Futures with margin payments calls & $92 \%$ & $8 \%$ & $0 \%$ & $0 \%$ & $0 \%$ \\
\hline Minimum government intervention & $75 \%$ & $17 \%$ & $0 \%$ & $8 \%$ & $0 \%$ \\
\hline Forward contract involving a bank & $50 \%$ & $17 \%$ & $17 \%$ & $8 \%$ & $8 \%$ \\
\hline Swap arrangement including a bank & $42 \%$ & $8 \%$ & $25 \%$ & $17 \%$ & $8 \%$ \\
\hline Options \& futures linked to global markets & $58 \%$ & $17 \%$ & $8 \%$ & $0 \%$ & $17 \%$ \\
\hline Use of a clearing house \& settlement system & $83 \%$ & $17 \%$ & $0 \%$ & $0 \%$ & $0 \%$ \\
\hline Futures contract with market order & $50 \%$ & $42 \%$ & $0 \%$ & $0 \%$ & $8 \%$ \\
\hline Futures contract with limit order & $75 \%$ & $25 \%$ & $0 \%$ & $0 \%$ & $0 \%$ \\
\hline Futures contract with stop loss order & $58 \%$ & $34 \%$ & $8 \%$ & $0 \%$ & $0 \%$ \\
\hline Futures contract with a stop limit order & $67 \%$ & $33 \%$ & $0 \%$ & $0 \%$ & $0 \%$ \\
\hline
\end{tabular}

Table 9: Best practice use of using derivatives in the foreign currency markets of South Africa. 
Citation: Chidaushe WK (2018) The Impediments and Best Practice use of Derivatives in Zimbabwe, Botswana and South Africa. J Bus Fin Aff 7 : 333. doi: $10.4172 / 2167-0234.1000333$

Page 10 of 12

\begin{tabular}{|c|c|c|c|c|c|}
\hline & $\begin{array}{l}\text { Strongly } \\
\text { agree }\end{array}$ & $\begin{array}{l}\text { Tend to } \\
\text { agree }\end{array}$ & $\begin{array}{l}\text { Neither agree nor } \\
\text { disagree }\end{array}$ & $\begin{array}{l}\text { Tend to } \\
\text { disagree }\end{array}$ & $\begin{array}{l}\text { Strongly } \\
\text { disagree }\end{array}$ \\
\hline \multicolumn{6}{|l|}{ Best practice use: } \\
\hline Marking to market the futures & & & $100 \%$ & & \\
\hline Futures with margin payments calls & & & $100 \%$ & & \\
\hline Minimum government intervention & $4 \%$ & $17 \%$ & $79 \%$ & & \\
\hline Forward contract involving a bank & $8 \%$ & $13 \%$ & $79 \%$ & & \\
\hline Swap arrangement including a bank & $8 \%$ & $4 \%$ & $88 \%$ & & \\
\hline Options \& futures linked to global markets & $4 \%$ & $0 \%$ & $96 \%$ & & \\
\hline Use of a clearing house $\&$ settlement system & $13 \%$ & $8 \%$ & $79 \%$ & & \\
\hline Futures contract with market order & & & $100 \%$ & & \\
\hline Futures contract with limit order & & & $100 \%$ & & \\
\hline Futures contract with stop loss order & & & $100 \%$ & & \\
\hline Futures contract with a stop limit order & & & $100 \%$ & & \\
\hline
\end{tabular}

Table 10: Best practice use of using derivatives in the foreign currency markets of Botswana

\begin{tabular}{|c|c|c|c|c|c|}
\hline & $\begin{array}{c}\text { Strongly } \\
\text { agree }\end{array}$ & $\begin{array}{l}\text { Tend to } \\
\text { agree }\end{array}$ & $\begin{array}{c}\text { Neither agree nor } \\
\text { disagree }\end{array}$ & $\begin{array}{c}\text { Tend to } \\
\text { disagree }\end{array}$ & $\begin{array}{l}\text { Strongly } \\
\text { disagree }\end{array}$ \\
\hline \multicolumn{6}{|l|}{ Best practice use: } \\
\hline Marking to market the futures & & & $100 \%$ & & \\
\hline Futures with margin payments calls & & & $100 \%$ & & \\
\hline Minimum government intervention & $38 \%$ & $18 \%$ & $44 \%$ & & \\
\hline Forward contract involving a bank & $0 \%$ & $12 \%$ & $88 \%$ & & \\
\hline Swap arrangement including a bank & & & $100 \%$ & & \\
\hline Options \& futures linked to global markets & & & $100 \%$ & & \\
\hline Use of a clearing house \& settlement system & & & $100 \%$ & & \\
\hline Futures contract with market order & & & $100 \%$ & & \\
\hline Futures contract with limit order & & & $100 \%$ & & \\
\hline Futures contract with stop loss order & & & $100 \%$ & & \\
\hline Futures contract with a stop limit order & & & $100 \%$ & & \\
\hline
\end{tabular}

Table 11: Best practice use of using derivatives in the foreign currency markets of Zimbabwe.

\begin{tabular}{|c|c|c|c|c|c|}
\hline & $\begin{array}{c}\text { Very huge } \\
\text { impact }\end{array}$ & $\begin{array}{l}\text { Fairly huge } \\
\text { impact }\end{array}$ & $\begin{array}{c}\text { Not a fairly huge } \\
\text { impact }\end{array}$ & $\begin{array}{l}\text { Do not have an } \\
\text { impact at all }\end{array}$ & Do not know \\
\hline \multicolumn{6}{|l|}{ Derivative instrument } \\
\hline Options & $42 \%$ & $33 \%$ & & & $25 \%$ \\
\hline Futures & $68 \%$ & $7 \%$ & & & $25 \%$ \\
\hline Grain futures \& options & $50 \%$ & $17 \%$ & $8 \%$ & & $25 \%$ \\
\hline Soy complex futures & $33 \%$ & $8 \%$ & $25 \%$ & $8 \%$ & $25 \%$ \\
\hline Soft red wheat futures & $17 \%$ & $8 \%$ & $42 \%$ & $8 \%$ & $25 \%$ \\
\hline Hard red winter & $17 \%$ & $0 \%$ & $42 \%$ & $8 \%$ & $33 \%$ \\
\hline Corn futures \& options & $25 \%$ & $25 \%$ & $25 \%$ & $0 \%$ & $25 \%$ \\
\hline Gold futures \& options & $17 \%$ & $17 \%$ & $25 \%$ & $8 \%$ & $33 \%$ \\
\hline Copper futures \& options & $8 \%$ & $25 \%$ & $17 \%$ & $17 \%$ & $33 \%$ \\
\hline Silver futures \& options & $8 \%$ & $25 \%$ & $17 \%$ & $17 \%$ & $33 \%$ \\
\hline Crude oil futures \& options & $25 \%$ & $25 \%$ & $17 \%$ & $0 \%$ & $33 \%$ \\
\hline Diesel hedge futures \& options & $17 \%$ & $17 \%$ & $33 \%$ & $8 \%$ & $25 \%$ \\
\hline Interest rate collar & $17 \%$ & $17 \%$ & $0 \%$ & $17 \%$ & $49 \%$ \\
\hline Weather & $0 \%$ & $17 \%$ & $8 \%$ & $8 \%$ & $67 \%$ \\
\hline Real estate & $0 \%$ & $17 \%$ & $8 \%$ & $8 \%$ & $67 \%$ \\
\hline Diamond futures & $8 \%$ & $0 \%$ & $8 \%$ & $8 \%$ & $76 \%$ \\
\hline Beef futures & $8 \%$ & $8 \%$ & $25 \%$ & $0 \%$ & $34 \%$ \\
\hline
\end{tabular}

Table 12: Impact on payoff of derivatives in addressing risk in the foreign currency markets of South Africa.

Applying options and futures in the markets have a huge impact on pay-off in addressing risk in the financial and commodity markets of South Africa.

\section{Conclusion}

\section{Zimbabwe}

Wrong political priorities and bad governance decisions in
Zimbabwe have resulted in economic chaos and uncertainties causing the country's economy to plummet and marred with corruption resulting in economic sanctions imposed against the country by the international community.

It is proclaimed that economic sanctions imposed againstZimbabwe, for instance through the Zimbabwe Democracy and Economic Recovery Act of 2001 (ZDERA Act of 2001) by the United States Congress, have 
significantly contributed to the failure of the country to implement meaningful economic recovery and reconstruction programs aimed at implementing commodity derivatives in the financial markets.

The bad governance coupled with economic sanctions has over the years caused significant contraction of the domestic financial sector and subsequently fuelled brain drain of financial experts to other states. This has suppressed and impinged on the much-needed economic prosperity of the country. The volatile political climate has in turn caused dramatic defects in the legal, contractual and economic factors upon which the implementation of the derivatives could have thrived upon.

The research uncovered that Zimbabwe does not have a derivatives market within its economic jurisdiction, apart from using simple forward contracts to hedge against risk. The market is described as equity centric.

It has been asserted that some banks in Zimbabwe use special Forward Rate Arrangements to hedge risk in loan contracts, as well as in money market investments and bid bonds with exceptional customers. Apart from this arrangement most banks commonly use asset liability matching and the duration gap analysis as risk management tools.

However, on a positive note Zimbabwe is awaiting to gazette the alternative trading platform framework that will facilitate the provision of derivative trading in the market when the economic uncertainties and conditions eventually improve.

\section{Botswana}

Botswana with its associated political, legal and economic stability uses a few derivative instruments such as simple forward contracts, foreign exchange swaps, and currency options to hedge risk in the market. This has been the result of failure by economic planners to overcome strategic drift over the years. This has caused the developments on the local exchange to lag behind that of the Johannesburg Stock Exchange (JSE) in South Africa.

Lack of knowledge and relevant expertise to account for derivatives and skeptical perceptions have been the demise of developing a broad and flexible institutional legal and other contractual framework to cater for the use of derivatives in the economy.

In Botswana derivative trading is provided for in legislation, albeit this provision exists in the legislation for the implementation of derivatives, a derivative market is not yet operational in Botswana.

Botswana has a few commodities being traded on the local stock exchange; it does not have a regulated derivative market for the purpose of hedging exposures in the market. The economy of Botswana is equity centric just like their counterparts in Zimbabwe.

In Botswana diesel or fuel is highly subsidized as such the local fuel pump prices do not mimic the actual market trends of the crude oil price movements and as a result using derivatives to hedge against the price risk of changing prices for crude oil in Botswana would not be pragmatic as for now.

In Botswana commodity derivatives are not traded, as there are no structures in place and there is a very little risk appetite to make it a feasible option. According to Pickel adequate infrastructure need to be put in place to support the evolution of innovative derivatives products [15].

In Botswana most banks and financial institutions do not have a mandate to hedge risk using derivative products. However, the NonBanking Financial Regulation Authority(NBFIRA) of Botswana intends to resuscitate the existing legal and other contractual framework to afford for the implementation and to promote the broad use of financial instruments in Botswana later in the long term.

\section{South africa}

In South Africa bad governance turmoil have been rising steadily in recent years fuelled by corruption resulting in some economic uncertainty and imbalances adversely affecting the risk appetite of investors and the extent to which derivatives are used the economy.

In South Africa use of derivatives has been on the rise over the years with trading volumes of over seven million during March 2014, which has been a great accolade for the market, but as of recent years South Africa has been experiencing some economic turbulences resulting from bad governance.

Complex commodities and derivatives products evolved over the years in South Africa, which has been contributed by positive economic reforms in the state, this has led to changes in the manner in which the derivatives are priced.

In South Africa forward contracts are entered into as standardized contracts and swap arrangements are dealt with as standardized contracts that exchange the principal to all deals.

It can be concluded that in South Africa currency futures, forward contracts, currency options and currency quanto futures and futures integrated with international exchange markets pricing mechanism, such as of Chicago mercantile exchange (CME), are effective at addressing exposures in the foreign exchange markets of South Africa.

Finally, it can be asserted that use of derivatives do not provide complete immune against losses, huge losses occasional occur in the market when derivatives are used badly and inappropriately, for instance without aligning them to the contractual objectives and the client's risk/ return profile and the effects of basis risk for futures contract.

\section{Acknowledgements}

I would like to especially thank the following for the support and contributions rendered to me by the following persons without which it would have been impossible to add practical value to the research findings, pastor Biggie Ganda Butale (Honourable Assistant minister investments, trade and industry), Dr. Tapiwa Gande, Arthur Buchner (Courtney Capital Management), Dianne Bates (Rand merchant Bank), Johann Reinecke (Bester Derivative trading), Jannie van der Watt (Grocapital Broking Services), Ruan Erasmus (VKB Graan), James Bucknall (GWK Trading), Giancarlo Filomeno (CJS Securities), Jaco Nell (Sigma Options Writers), Hendrick Bester (Unigrain Trading, Edward Chris (ABSA Bank), Veronica Sehoole (JSE), Gorata Molojwane (NBFIRA), Mbaakanyi Mafa (NDB) Odirile Pilane (Stanbic Bank), Kealeboga Mogodi (Stanbic Bank), Harriet Mlalazi (FNB), Tirivafi Nhundu (ZSEC), Andrew Matangaidze (Invictus), Shanangurai Takaindisa (NMBZ), Tafadzwa Hamandishe (CBZ) and Ernest Masvavike (CBZ) -Dr. Chawawa, Violet Ndigune.

\section{References}

1. Greenberger (2010) The role of derivatives in the financial crisis. University of Maryland school of law, USA.

2. Hull J (2012) Options, Futures and other derivatives. (8th edn.), Prentice Hall, New York.

3. IOSCO (1994) Report of the development committee task force on derivatives

4. Huberman M, Robson (1994) Conceptual Framework: What do you think is going on? Sage Publications.

5. Jabareen Y (2009) Building a conceptual framework: Philosophy, definitions, and procedure. International Journal of Qualitative Methods 8: 49-62.

6. Guba EG, Lincoln YS (1994) Competing paradigms in qualitative research Thousands Oaks, Sage, CA, pp: 105-117. 
Citation: Chidaushe WK (2018) The Impediments and Best Practice use of Derivatives in Zimbabwe, Botswana and South Africa. J Bus Fin Aff 7: 333. doi: $10.4172 / 2167-0234.1000333$

7. Glaser BG, Strauss AL (1967) The discovery of grounded theory: Strategies for qualitative research. Aldine, Chicago.

8. Liehr P, Smith M (2001) Frameworks for Research

9. Gibson R (1991) Option Valuation. J Financ, pp: 959-976.

10. Tsetsekos G, Varangis $P$ (1997) The Structure of Derivative Exchange: Lessons from Developed and Emerging Markets. The World Bank Observer 5: 85-92

11. Bodie Z, Kane A, Marcus AJ, Mohanty P (2005) Investments. (6th edn.), McGraw-Hill Publishing Co. Ltd., New Delhi.

12. Adelegan OJ (2009) The derivatives market in South Africa: Lessons for subSaharan African countries.

13. Banks E (2003) Exchange-traded derivatives. John Wiley \& Sons Ltd, England.

14. Bekale AN (2014) Institutionalization of derivatives trading and economic growth: Evidence from South Africa.

15. Pickel R (2006) Evolution and intelligent design: Developing the derivatives infrastructure. Capital Markets Law Journal 1:17-183.

16. Hawkesky C (2000) A Primer on Derivative Markets. Reserve Bank of New Zealand Bulletin 62: 24-43.

17. Baluch A, Ariff M (2007) Derivatives markets and economic growth: Is there a relationship? Australia: Bond University Globalisation \& Development Centre.

18. Alberta Market Solutions (2003) Derivatives market development: Key success factors in building a new derivatives market. White Paper from Alberta Market Solutions Ltd.

19. Standley S (2010) What are the determinants of financial market development in sub-Saharan Africa? Africa's Financial Markets: A Real Development Tool? 5: $17-19$

20. Haiss PR, Sammer B (2010) The impact of derivatives markets on Financial Integration, Risk and Economic growth.

21. Hamilton A (1998) Definitions.

22. Deutsche Bundesbank Monthly Report (2006) Derivatives and their feedback effects on the spot markets.

23. Chisholm MA (2004) Derivatives Demystified: A Step by Step Guide in Forwads, Swaps, Futures and Options. John Wiley and Sons Ltd. Southern gate England.

24. Chagwiza W (2013) Liquidity derivatives as solution to Zimbabwean economic liquidity problems.

25. Dodd F (2010) Dodd-Frank wall street reform and consumer protection act. Public Law, pp: 111-203.

26. Tian L (2005) Necessity of Establishment of Financial Derivative Market in China. The Journal of American Science 1: 87-90.

27. Bessis J (2002) Risk Management in Banking. (4th edn), John Wiley and Sons Ltd

28. Sendeniz-Yüncü I, Akdeniz L, Aydogan K (2007) Futures market development and economic growth.

29. Kumari S (2011) An insight into derivative markets: Indian perspective International Journal of Research in Finance \& Marketing 1: 25-37.

30. Ngugi R, Amanja D, Maana I (2009) Capital market, financial deepening and economic growth in Kenya.

31. Rodrigues P, Schwarz C, Seeger N (2012) Does the institutionalization of derivatives trading spur economic growth?

32. Kirkpatrick C (2000) Financial development, economic growth, and poverty reduction. The Pakistan Development Review 39: 363-388.

33. Nhavira JDG (2013) Financial regulation and supervision in Zimbabwe: An evaluation of adequacy and options.
34. Crotty MJ (1998) The foundations of social research: Meaning and perspective in the research process. London: Sage.

35. Chilisa B, Preece J (2005) African perspective in Adult learning: Research methods for adult educators. Hamburg, German: UNESCO Institute of Education.

36. Lincoln YS, Guba EG (1985) Naturalistic Inquiry. Newbury Park, Sage.

37. McMillan JH, Schumacher S (2006) Research in education: Evidence-Based Inquiry. (7th edn.), Pearson Education, Inc, New York.

38. Scotland J (2012) Exploring the Philosophical Underpinnings of Research: Relating Ontology and Epistemology to the Methodology and Methods of the Scientific, Interpretive, and Critical Research Paradigms. Canadian Center of Science and Education 5: 9-16.

39. Kuhn TS (1962) The structure of scientific revolutions. (2nd edn), Chicago Uni. Chicago Press, USA.

40. Cohen L, Manion L, Morrison K (2007) Research methods in education. (6th edn), Routledge, London.

41. Bloomberg LD, Volpe M (2008) Completing your qualitative dissertation: A roadmap from beginning to end. Thousand Oaks: CA, Sage.

42. Rowley J (2002) Using case studies in research. Management Research News 25: 16-27.

43. Yin RK (2009) Case study research: Design and methods. (4th edn), Thousand oaks, Calif: Sage.

44. Creswell JW (2009) Research design: Qualitative, quantitative, and mixed methods approach. (3rd edn.), Thousand Oaks, Sage.

45. Stake R (1995) The art of case study research. Thousand Oaks, Sage, CA, pp: $49-68$.

46. Adelman C (1980) Rethinking Case Study: Notes from the Second Cambridge Conference. In: Simons H editor. Towards a Science of the Singular. Centre for Applied Research in Education, University of East Anglia, pp: 45- 61.

47. Merriam SB (2009) Qualitative research: A guide to design and implementation. (2nd edn.), San Francisco, CA: Jossey-Bass.

48. Kaplan RS (1986) The role of empirical research in management accounting Account Org Soc 11: 429-452.

49. Parkhe A (1993) 'Messy' research, methodological predispositions, and theory development in international joint ventures. Acad Manage Rev 18: 227-268.

50. Orlikowski W, Baroudi JJ (1991) Studying information technology in organizations: research approaches and assumptions. Information Systems Research 2: 1-14.

51. Eisenhardt KM (1989) Building theories from case study research. Acad Manage Rev 14: 532-550.

52. Merriam SB (1998) Qualitative research and case study applications in education. (2nd edn.), San Francisco: Jossey-Bass Publishers.

53. Bonoma TV (1985) Case research in marketing: opportunities, problems, and a process. J Mark Res 22: 199-208.

54. Stake RE (1994) Qualitative Case Studies. Thousand Oaks, Sage.

55. Gilmore A, Carson D (1996) Integrative qualitative methods in a services context. Marketing Intelligence and Planning 14: 21-26.

56. Hirschman EC (1986) Humanistic inquiry in marketing research: philosophy, method, and criteria. Journal of Marketing Research 23: 237-249.

57. Bernard HR (2002) Research Methods in Anthropology: Qualitative and quantitative Approaches. (3rd edn.), AltaMira Press, Walnut Creek, California.

58. Shaw E (1999) A guide to the qualitative research process: Evidence from small firm study. Qualitative Market Research: An International Journal 2: 59-70.

59. Saunders M, Lewis P, Thornhill A (2007) Research Methods for Business Students. (5th edn.), Financial Times Prentice Hall, Edinburgh Gate, Harlow. 